\title{
Livelihood Analysis on Economic Conditions in Jelobo Village, Klaten Regency, Central Java
}

\author{
Soni Setiawan ${ }^{1, *}$ Juhadi $^{2,}$ Eva Banowati ${ }^{3,}$ Tjaturahono Budi Sanjoto ${ }^{4}$ \\ ${ }^{1,2,3.4}$ Geografi Departement Faculty of Social Sciences Universitas Negeri Semarang \\ "Corresponding author. Email: Sony.qwerty17@gmail.com
}

\begin{abstract}
The development of villages and rural areas is an important factor for regional development, poverty alleviation, and reduction of the gap between regions through participatory development approaches. Based on the age of work in Jelobo village there are 2,507 people[2] with a lot of working-age can be a cornerstone to improve the economy of the village. From the explanation above, the purpose of this research is (1) taken to know the potential condition of human resources in Jelobo village and (2) know the conditions of livelihood in the economic sector as a database for Village development. The population in this study is a household in Jelobo village with data collection techniques using observation methods and document data from the Central Statistics Agency. Jelobo Village has the potential of human resources entered into the medium category of being measured using the parameters of the internal minister regulation No. 12 the year 2007. In the welfare parameters of Jelobo village, the results obtained 3.3\% low, 20\% medium, and 76.7\% high. For income level $66.7 \%$ low, $10 \%$ medium and $23 \%$ high income. While the level of dependence on agricultural land was $16.7 \%$ dependent on farmland and $83.3 \%$ were not.
\end{abstract}

Keywords: Human resources, welfare, income, level of dependence on farmland.

\section{INTRODUCTION}

The development of villages and rural areas is an important factor for regional development, poverty alleviation, and reduction of the gap between regions through participatory development approaches. The number of villages in Indonesia is 75,436 village and 8,444 Kelurahan (statistical potentials of Indonesia Village, 2018:13)[2] is a challenge for the Indonesian government today with the increasing number of villages should be followed by improving the welfare of the village community. In this case, the community welfare increase is the nature of national development. This level of community welfare reflects the quality of life of a family/household. Families with higher levels of welfare have a better quality of life, so in the end, the family can create better conditions to improve their welfare.

Jelobo Village is a village with a total area of 250.57 hectares with the widest area of rice fields in Wonosari, which is about 161 hectares. There are 4,405 inhabitants of Jelobo village. Based on the working-age 2,507 people are mostly in the livelihood of farmers 307 and Agricultural workers 216[2]. Based on the explanation, researchers want to know the condition of potential human resources in Jelobo village and know the condition of livelihood in the economic sector in Jelobo village.

\section{RESEARCH METHODS}

This research is a quantitative descriptive research that uses the parameter of determining the potential of human resources with scoring methods and analysis of sustainable livelihood indicators in the economic conditions in Jelobo village. The human resources potential in Jelobo village is calculated using the parameters of the internal minister regulation No. 12 the year 2007 which will be analyzed by the scoring method.

Human resource potential score value: 46 Lows and highest 165 .

- High Potency (> 80\% of maximum score/> 132)

- Moderate potency (60\%-80\% of the maximum score/99 - 132)

- Low potency $(<60 \%$ of Maximum score $/<99)$ 
The variables used are welfare levels, income levels, and the percentage of communities that depend on agricultural land[5]. The first variable is the level of household welfare using parameters from the Central Statistics Agency (2015) with the scoring method of each existing parameter with the result grouped into three categories:

- Low welfare, with an index of $<33.33$

- Moderate welfare, with indexes 33.34-66.66

- High welfare, with an index of $>66.67$

The second variable is the total income level of households from farmer income and non-farm income.

$\mathrm{P}_{\mathrm{rt}}=\mathrm{P}$ on-farm $+\mathrm{P}$ off-farm $+\mathrm{P}$ non-farm

Description:

$\mathrm{P}_{\mathrm{rt}}=$ Household income

$\mathrm{P}$ on-farm = Income of farming

$\mathrm{P}$ off-farm = Agricultural sector revenue outside of farming activities

P non-farm $=$ Income from outside the farm.

The third variable is the percentage of people who depend on agricultural land with the following calculations:

$$
V=\frac{I}{M} \times 100
$$

Description:

$V=$ Percentage of communities that depend on farmland

$I=$ Communities that depend on agricultural land

$M=$ Total number of samples.

Table 1. Human resources potential
From the data of total household income results classified by parameters that divide the income level into 3 levels, namely high income $(\geq \mathrm{Rp}$ $5,000,000$ per month), medium-income (Rp 3.100.000 - Rp 5.000.000 per month), and low income ( $\leq \mathrm{Rp}$ $3,000,000$ per month) some results show that members of the families such as wives and children are contributors to various activities both in housework and for a living[1].

\section{RESULTS AND DISCUSSION}

Jelobo Village, Wonosari subdistrict, Klaten Regency, Central Java province. Jelobo Village is a village located at an altitude of \pm 109 masl with an area of $250.57 \mathrm{Ha} / 2,505 \mathrm{Km} 2$. astronomically Jelobo Village located at 7037 ' 38.16 '-70 38 ' 53.16 "LS and 110044 ' 20.65"-1100 45 ' 19,29 "BT. The boundary of Jelobo Village is administratively limited by: The North is Kingkang village and Pandanan village, Wonosari The east is Kingkang village, Wonosari subdistrict and Carikan village, District Juwiring. The south is the village of Kwarasan, the district of Juwiring. The West is Lumbung Kerep village and Ngreden village, Wonosari subdistrict.

Analysis of human resources potential is based on potential data of population and gender, the potential of age and gender, potential of education and livelihood/occupation, potential of religion, potential of ethnic diversity and ethnic origin, labor, and population according to disability. From the results of data obtained by the potential human resources owned by Jelobo Village belongs to the category of medium potentials (Table 1).

\begin{tabular}{|c|l|c|c|}
\hline No & \multicolumn{1}{|c|}{ Village Potential } & Parameters & Score \\
\hline A & Population Density & 1692 people $/ \mathrm{km}^{2}\left(>1000\right.$ people $\left./ \mathrm{km}^{2}\right)$ & 8 \\
\hline B & Age Development & $2280(18-56$ year $)$ & 8 \\
\hline C & Education Level & $<10 \%$ & 3 \\
\hline 1 & $\begin{array}{l}\text { Total of 7-18 Year Olds Who Are Not In } \\
\text { School }\end{array}$ & $10-25 \%$ & 2 \\
\hline 2 & $\begin{array}{l}\text { Total of 12-56 Year Olds Who Never Went } \\
\text { to School }\end{array}$ & $10-25 \%$ & 2 \\
\hline 3 & $\begin{array}{l}\text { Total of 12-56 Year Olds Who Did Not } \\
\text { Finish Elementary School }\end{array}$ & $10-25 \%$ & 2 \\
\hline 4 & $\begin{array}{l}\text { Total of 12-56 Year Olds Who Did Not } \\
\text { Finish Elementary School }\end{array}$ & $<10 \%$ & 5 \\
\hline 5 & $\begin{array}{l}\text { Total of 18-56 Year Olds Who Did Not } \\
\text { Finish High School }\end{array}$ & $<10 \%$ & 5 \\
\hline 6 & SLB Graduation & 10 type (5-10 type) & 4 \\
\hline D & Basic Livelihoods & & \\
\hline 1 & Total of Basic Livelihood Types & & \\
\hline E & Religion & & \\
\hline
\end{tabular}




\begin{tabular}{|c|c|c|c|}
\hline No & Village Potential & Parameters & Score \\
\hline 1 & Total religion Embraced & 2 religion & 6 \\
\hline 2 & Total of Believers & $<1 \%$ total population & 4 \\
\hline $\mathbf{F}$ & Citizenship & All Indonesian Citizens & 5 \\
\hline G & Ethnicity & & \\
\hline 1 & Integration of Society & 2-5 Ethnicity & 2 \\
\hline $\mathbf{H}$ & Cacat Mental dan Fisik & & \\
\hline 1 & Mental and Physical Disabilities & 16 people $(<0,1 \%$ total population $)$ & 5 \\
\hline I & Labor & & \\
\hline 1 & Population ages 18-56 Years Not Working & $35,53 \%(26-50 \%)$ & 2 \\
\hline 2 & Population ages 18-56 Year Work & $64,47 \%(>50 \%)$ & 10 \\
\hline 3 & Work Dependency Rate & $46,30 \%(26-50 \%)$ & 4 \\
\hline $\mathbf{J}$ & Quality of the Workforce & & \\
\hline 1 & $\begin{array}{l}\text { Population ages } 18-56 \text { Year Illiteracy and } \\
\text { Letters / Numbers Latin }\end{array}$ & $11-25 \%$ & 3 \\
\hline 2 & $\begin{array}{l}\text { Population aged } 18-56 \text { years who did not } \\
\text { complete primary school }\end{array}$ & $11-25 \%$ & 3 \\
\hline 3 & $\begin{array}{l}\text { Population aged 18-56 years who completed } \\
\text { elementary school }\end{array}$ & $51-75 \%$ & 4 \\
\hline 4 & $\begin{array}{l}\text { Population aged 18-56 years who completed } \\
\text { junior high school }\end{array}$ & $26-50 \%$ & 4 \\
\hline 5 & $\begin{array}{l}\text { Population aged } 18-56 \text { years who have } \\
\text { completed high school }\end{array}$ & $26-50 \%$ & 6 \\
\hline 6 & $\begin{array}{l}\text { Population aged 18-56 years who graduated } \\
\text { from college }\end{array}$ & $<10 \%$ & 6 \\
\hline \multicolumn{3}{|c|}{$\begin{array}{ll} & \text { Total }\end{array}$} & 103 \\
\hline
\end{tabular}

Source: The Data from Wonosari subdistrict in the year number 2019

Participation community is important to note, in the development of villages inseparable from activities to empower human resources to manage and utilize all potentials and components owned by the village for the advancement and improvement of the welfare of the community. The development of villages and rural areas is an important factor for regional development, poverty alleviation, and reduction gaps between regions through a participatory development approach.

Village potential is the power, strength, ability, and ability of a village which can be developed in increasing community welfare (Ahmad, 2017: 32). In the data processing results of Jelobo Hamlet (table 2), the results of household welfare of $50 \%$ are located at medium welfare and 50\% are households with high welfare levels. As for the income level, only $10 \%$ of households have high-income levels and $90 \%$ of other households have low-income levels. For the level of dependence on farmland, Jelobo Hamlet only has $10 \%$ of households that depend on agricultural land while $90 \%$ are not.

Table 2. Research Results of Jelobo Hamlet

\begin{tabular}{|c|c|c|c|c|c|c|c|c|}
\hline & \multicolumn{3}{|c|}{ Welfare } & \multicolumn{3}{c|}{ Income } & \multicolumn{2}{c|}{$\begin{array}{c}\text { Dependence On } \\
\text { Farmland }\end{array}$} \\
\cline { 2 - 9 } & Low & Medium & High & Low & Medium & High & Depend & Undepend \\
\hline Total & 0 & 5 & 5 & 9 & 0 & 1 & 1 & 9 \\
\hline Percentage & $0 \%$ & $50 \%$ & $50 \%$ & $90 \%$ & $0 \%$ & $10 \%$ & $10 \%$ & $90 \%$ \\
\hline
\end{tabular}

Source: Data Processing, 2020

For the result of field data processing in Wantilan Hamlet (table 3) The result of household welfare is $90 \%$ of households are located high welfare while only $10 \%$ have low welfare level. At the household income level, $60 \%$ was left low, $10 \%$ were at moderate-income, and $30 \%$ at high revenue level. With the level of dependence on farmland only $10 \%$ sealift $90 \%$ other not. 
Table 3. Research Results of Wantilan Hamlet

\begin{tabular}{|c|c|c|c|c|c|c|c|c|}
\hline & \multicolumn{3}{|c|}{ Welfare } & \multicolumn{3}{c|}{ Income } & \multicolumn{3}{c|}{$\begin{array}{c}\text { Dependence On } \\
\text { Farmland }\end{array}$} \\
\cline { 2 - 11 } & Low & Medium & High & Low & Medium & High & Depend & Undepend \\
\hline Total & 1 & 0 & 9 & 6 & 1 & 3 & 3 & 7 \\
\hline Percentage & $10 \%$ & $0 \%$ & $90 \%$ & $60 \%$ & $1 \%$ & $30 \%$ & $30 \%$ & $70 \%$ \\
\hline
\end{tabular}

Source: Data Processing, 2020

Ngrodon Hamlet data Processing result (table 4) obtained results in household welfare level only $10 \%$ of households are at a moderate welfare level and $90 \%$ are at high welfare level. At the income level, there are
$50 \%$ yield at a low level, $20 \%$ at a medium rate, and $30 \%$ high revenue rate. While the level of dependence on agricultural land there are $30 \%$ of households depend on agricultural land and $70 \%$ are not.

Table 4. Research Results of Ngrodon Hamlet

\begin{tabular}{|c|c|c|c|c|c|c|c|c|}
\hline & \multicolumn{3}{|c|}{ Welfare } & \multicolumn{3}{c|}{ Income } & \multicolumn{3}{c|}{$\begin{array}{c}\text { Dependence On } \\
\text { Farmland }\end{array}$} \\
\cline { 2 - 10 } & Low & Medium & High & Low & Medium & High & Depend & Undepend \\
\hline Total & 0 & 1 & 9 & 5 & 2 & 3 & 3 & 7 \\
\hline Percentage & $0 \%$ & $10 \%$ & $90 \%$ & $50 \%$ & $20 \%$ & $30 \%$ & $30 \%$ & $70 \%$ \\
\hline
\end{tabular}

Source: Data Processing, 2020

In the welfare parameters of Jelobo village, the results obtained $3.3 \%$ low, 20\% moderate, and $76.7 \%$ high. For income level $66.7 \%$ low, $10 \%$ moderate, and $23.3 \%$ high income. While the level of dependence on agricultural land was $16.7 \%$ dependent on farmland and $83.3 \%$ were not, can be read in table 5 .

Table 5. Research Results of Jelobo Village

\begin{tabular}{|c|c|c|c|c|c|c|c|c|}
\hline & \multicolumn{3}{|c|}{ Welfare } & \multicolumn{3}{c|}{ Income } & \multicolumn{3}{c|}{$\begin{array}{c}\text { Dependence On } \\
\text { Farmland }\end{array}$} \\
\cline { 2 - 10 } & Low & Medium & High & Low & Medium & High & Depend & Undepend \\
\hline Total & 1 & 6 & 23 & 20 & 3 & 7 & 7 & 23 \\
\hline Percentage & $3.3 \%$ & $20 \%$ & $76.7 \%$ & $66.7 \%$ & $10 \%$ & $23.3 \%$ & $16.7 \%$ & $83.3 \%$ \\
\hline
\end{tabular}

Source: Data Processing, 2020

The development of village potential can be developed from knowing the problems that exist in the village itself, the description of problems in the village can be the basis for making policies and activities that can increase community empowerment in optimizing the village potential so that the direction of village development becomes more focused and effective.

\section{CONCLUSION}

Jelobo Village has the potential of human resources entered into the category of being measured using the parameters of the domestic minister regulation No. 12 years 2007 consisting of 10 variables. While the data obtained by Jelobo village has a poor level of welfare compared to the Wantilan Hamlet and Ngrodon Hamlet, the percentage of welfare level 50\% is located at moderate prosperity and $50 \%$ is a household that has a high level of welfare. The income level of the Jelobo hamlet is getting a low-income level with other hamlets, with $90 \%$ of households having low-income levels and $10 \%$ of other households with high-income levels. This can be a concern in the development of the village, with more attention to the empowerment of the community through entrepreneurial training and other things. As for the level of dependency on the farmland, Ngrodon has a higher level of dependence compared with other hamlets, with $30 \%$ dependence rate and $70 \%$ are not dependent on agricultural land.

\section{REFERENCES}

[1] Afiati Ratih, Eva Banowati, dan Ananto Aji. 2017. Kontribusi Usahatani Tanaman Jagung Program Phbm Terhadap Pendapatan Penduduk Desa Kaligayam Kecamatan Margasari Kabupaten Tegal. GeoImage.

[2] Badan Pusat Statistik. 2019. Kecamatan Wonosari Dalam Angka 2018. Klaten: Badan Pusat Statistik Kabupaten Klaten. 
[3] Hutasoit, Maylani Florensi. 2018. Analisis Pendapatan Dan Tingkat Kesejahteraan Rumah Tangga Petani Kopi Di Kecamatan Ulu Belu Kabupaten Tanggamus. Lampung: Fakultas Pertanian Universitas Lampung.

[4] Komala Sari Dian, Dwi Haryono, dan Novi Rosanti. 2014. Analisis Pendapatan Dan Tingkat Kesejahteraan Rumah Tangga Petani Jagung Di Kecamatan Natar Kabupaten Lampung Selatan. Jurnal Agribisnis. Vol. 2. No. 1.

[5] Martopo Anton, Gagoek Hardiman, dan Suharyanto. 2012. Kajian Tingkat Penghidupan Berkelanjutan (Sustainable Livelihood) Di Kawasan Dieng (Kasus Di Dua Desa Kecamatan Kejajar Kabupaten Wonosobo). Semarang: Fakultas Teknik Universitas Diponegoro.

[6] Rosni. 2017. Analisis Tingkat Kesejahteraan Masyarakat Nelayan Di Desa Dahari Selebar Kecamatan Talawi Kabupaten Batubara. Jurnal Geografi. Vol. 9. No. 1. 